\title{
Effects of organic acids and low pH on Rhizobium meliloti 104A14
}

\author{
Ricardo Perez-Galdona† and Michael L. Kahn
}

Author for correspondence: Michael L. Kahn. Tel: +1 509 335-3412. Fax: +1 509 335-7643.

Institute of Biological Chemistry, Washington State University, Pullman, Washington 99164-6340, USA

\begin{abstract}
In the symbiotic relationship between Rhizobium meliloti and alfalfa (Medicago sativa), the bacteria are enclosed within the plant cell by a membrane that may function like a plant vacuolar membrane and maintain a pH between 5.5 and 6.0. Free-living Rhizobium meliloti 104A14 is sensitive to $\mathrm{pH}$ in this range and its sensitivity was influenced by the presence of acetate and other monocarboxylic acids. R. meliloti can grow at pH 6.0 in $3 \mathrm{mM}$ succinate but does not grow at pH 6.2 if $10 \mathrm{mM}$ acetate is added. The combination of low pH and acetate is bacteriostatic. Measurement of internal $\mathrm{pH}\left(\mathrm{pH}_{\mathrm{i}}\right)$ using $14 \mathrm{C}$-labelled benzoate as a permeant acid showed that growth inhibition occurs when $\mathrm{pH}_{\mathrm{i}}$ falls below 7-15.
\end{abstract}

Keywords: Rhizobium meliloti, $\mathrm{pH}$ sensitivity, organic acids

\section{INTRODUCTION}

Bacterial acid tolerance depends on the cell maintaining an intracellular $\mathrm{pH}$ that is satisfactory for cell functions. Symbiotic, dinitrogen-fixing rhizobia are particularly sensitive to low $\mathrm{pH}$ and even moderately acid conditions are able to limit bacterial growth and the initiation of nitrogen-fixing nodules on the roots of host plants (Graham \& Parker, 1964; O'Hara et al., 1989). Within the plant cell, the symbiotic bacteria or bacteroids may also have to tolerate relatively acid conditions. Bacteroids are enclosed within a plant-derived symbiosomal membrane and similarities between symbiosomes and plant vacuoles have been found (Mellor, 1989). Acidic $\mathrm{pH}$ values between 5.5 and 6.0 are characteristic of vacuoles (Roberts et al., 1980). Transport of protons or singly ionized dicarboxylic acids across the symbiosome membrane has been proposed to acidify symbiosomes (Miller et al., 1988; Udvardi \& Kahn, 1992). Like vacuoles, symbiosomes contain a number of acid activated hydrolases (Mellor, 1989). Rhizobium leguminosarum bacteroids express an antigen that is also detected in free-living cells grown under acidic conditions (Kannenberg \& Brewin, 1989), which also suggests that bacteroid development occurs at acidic $\mathrm{pH}$.

The low oxygen concentration that occurs in root nodules would be expected to alter pathways of bacterial and plant carbon metabolism and under these conditions it is possible that monocarboxylic acids, such as acetic, pyruvic

†Present address: Departamento de Microbiologia y Biologia Celular, Universidad de La Laguna, 38206 La Laguna, Tenerife, Spain. or $\beta$-hydroxybutyric acid would be produced. Although these acids can be used as carbon sources by rhizobia, in other bacteria monocarboxylic acids have been shown to inhibit various functions, including substrate transport (Dijkhuizen et al., 1980), macromolecular synthesis (Cherrington et al., 1990, 1991) and regulation of cytoplasmic pH (Salmond et al., 1984; Baronofsky et al., 1984; Eklund, 1985). Inhibition is strongest at low $\mathrm{pH}$ values, suggesting that the unionized form of the acid plays a role in toxicity (Eklund, 1983). The aim of this work was to study the effect of acetic acid and other organic acids that are potential products of plant or bacterial carbon metabolism on the growth of free-living Rhizobium meliloti and on its ability to maintain its intracellular $\mathrm{pH}$.

\section{METHODS}

Bacterial strains and culture conditions. Rbizobium meliloti strains (Table 1) were maintained on a yeast extract mannitol salt medium (Vincent, 1970). Unless stated, rhizobia were grown in MM minimal medium (per litre: sodium succinate, $0.5 \mathrm{~g}$;

Table 1. Rhizobium meliloti strains

\begin{tabular}{|ll|}
\hline Strain & \multicolumn{1}{c|}{ Source or reference } \\
\hline $104 \mathrm{~A} 14$ & Somerville \& Kahn (1983) \\
1021 & Meade et al. (1982) \\
102F34 & Ditta et al. (1980) \\
102F28 & G. Ditta, San Diego \\
102F50Str & G. Ditta, San Diego \\
\hline
\end{tabular}


$\mathrm{NH}_{4} \mathrm{Cl}, 0.5 \mathrm{~g} ; \mathrm{K}_{2} \mathrm{HPO}_{4}, 1.0 \mathrm{~g} ; \mathrm{KH}_{2} \mathrm{PO}_{4}, 1.0 \mathrm{~g} ; \mathrm{Na}_{2} \mathrm{SO}_{4}, 0.25 \mathrm{~g}$; $\mathrm{FeCl}_{2} \cdot 6 \mathrm{H}_{2} \mathrm{O}, 0 \cdot 01 \mathrm{~g} ; \mathrm{CaCl}_{2} \cdot 2 \mathrm{H}_{2} \mathrm{O}, 0 \cdot 1 \mathrm{~g} ; \mathrm{MgCl}_{2} \cdot 6 \mathrm{H}_{2} \mathrm{O}, 0 \cdot 25 \mathrm{~g}$; biotin, $2 \mathrm{mg}$; thiamin, $2 \mathrm{mg}$ ) at $30^{\circ} \mathrm{C}$ on an orbital shaker at 200 r.p.m.

Effect of organic acids on growth. Bacteria were grown in MM and various organic acids were added to the cultures at final concentrations of 10 or $25 \mathrm{mM}$ during early exponential phase. Organic acids were dissolved in water, the $\mathrm{pH}$ was adjusted with sodium hydroxide and the solutions were filter sterilized immediately prior to addition. A Corning 150 specific ion meter using a Corning combination electrode was used to determine $\mathrm{pH}$ values. Growth was measured by optical density using a Klett-Summerson colorimeter equipped with a green filter. The $\mathrm{pH}$ of the cultures was measured periodically by withdrawing small samples. All chemicals, acids and buffers were obtained from Sigma.

Internal pH measurement. A modification of the method of Kashket (1981) was used to determine intracellular $\mathrm{pH}$. Bacteria were grown in $\mathrm{MM} \mathrm{pH} 6.7$ until late exponential phase $(\sim 50$ Klett units), collected by centrifugation at $14000 \mathrm{~g}$ at $4{ }^{\circ} \mathrm{C}$, washed twice and resuspended at a cell density corresponding to $200 \mu \mathrm{g}$ protein $\mathrm{ml}^{-1}$ (Bio- $\mathrm{Rad}$ ) in the appropriate buffer containing $3 \mathrm{mM}$ sodium succinate and other organic acids as indicated. Buffers used to establish the external $\mathrm{pH}$ at the indicated $\mathrm{pH}$ values were: $0 \cdot 1 \mathrm{M}$ MES $(\mathrm{pH} 5 \cdot 50,5.78$ or 6.01$)$, 0.1 M PIPES (pH 6.44 or 6.83) and $0.1 \mathrm{M}$ MOPS (pH 7.33). The suspension was shaken for $30 \mathrm{~min}$ at $30^{\circ} \mathrm{C}$. [7- $\left.{ }^{14} \mathrm{C}\right]$ Benzoic acid (DuPont-NEN) was added at $0.16 \mu \mathrm{Ci} \mathrm{ml}^{-1}\left(5.92 \mathrm{kBq} \mathrm{ml}^{-1}\right)$ and the incubation was continued for $15 \mathrm{~min}$ at $30^{\circ} \mathrm{C}$. Samples $(200 \mu \mathrm{l})$ were taken and the cells separated from the medium by centrifugation at 10000 r.p.m. for $1 \mathrm{~min}$ through $100 \mu \mathrm{l}$ of silicone oil [Fluid 510/Fluid 550 (Dow-Corning); 50:50, w/w] in $400 \mu \mathrm{l}$ microfuge tubes containing $15 \mu \mathrm{l} 15 \%$ (v/v) perchloric acid at the bottom, using a Fisher microfuge equipped with a swing-out rotor. The radioactivity in $100 \mu \mathrm{l}$ samples of the aqueous upper layer was used to determine the external concentration of $\left[7-{ }^{14} \mathrm{C}\right]$ benzoic acid. The microfuge tubes were then frozen in liquid nitrogen and the tips containing the bacterial cells were removed and transferred into liquid scintillation vials. ACS scintillation cocktail (Amersham) $(3 \mathrm{ml})$ was added and the radioactivity was determined in a Packard TriCarb 2000CA scintillation counter. To measure radioactivity that was bound non-specifically to the bacteria rather than contained within them, the cell membranes were permeabilized prior to adding radioactive benzoate by incubating the bacteria for $60 \mathrm{~min}$ at $30^{\circ} \mathrm{C}$ in the corresponding external $\mathrm{pH}$ buffer containing $2 \%$ toluene.

The intracellular volume was assumed to be $2 \cdot 4 \pm 0 \cdot 2 \mu \mathrm{l}$ (mg protein $)^{-1}$ (Tremblay \& Miller, 1984) and the internal $\mathrm{pH}$ was calculated by substituting the concentration ratio of benzoic acid as the weak acid into the equations of Maloney et al. (1975).

\section{RESULTS AND DISCUSSION}

The growth of $\mathrm{R}$. meliloti 104A14 on succinate as the sole carbon source was similar at initial $\mathrm{pH}$ values of 6.0 and 6.7 but was delayed significantly when the initial $\mathrm{pH}$ was 5.5 (Fig. 1). Growth observed in the latter culture was dependent on the gradual rise of $\mathrm{pH}$ observed as the culture was incubated; growth and the increase in $\mathrm{pH}$ were not seen when $10 \mathrm{mM}$ MES buffer was included in the medium. MES buffer did not affect the growth of cultures at $\mathrm{pH} 6.0$ or 6.7 (data not shown). The addition of acetate to similar cultures (Fig. 2) was inhibitory at lower
$\mathrm{pH}$ values - no growth was detected during $120 \mathrm{~h}$ of incubation at $\mathrm{pH}$ values equal to or lower than $6 \cdot 2$. When the $\mathrm{pH}$ values at the time acetate was added were 6.8 and 6.5 , the $\mathrm{pH}$ of the medium increased during the incubation to 8.7 and $8 \cdot 1$, respectively. When acetate was used as the sole carbon source, growth occurred only at $\mathrm{pH}$ values greater than $7 \cdot 3$ (data not shown). In all cultures where growth was seen, $\mathrm{pH}$ increases were also detected.
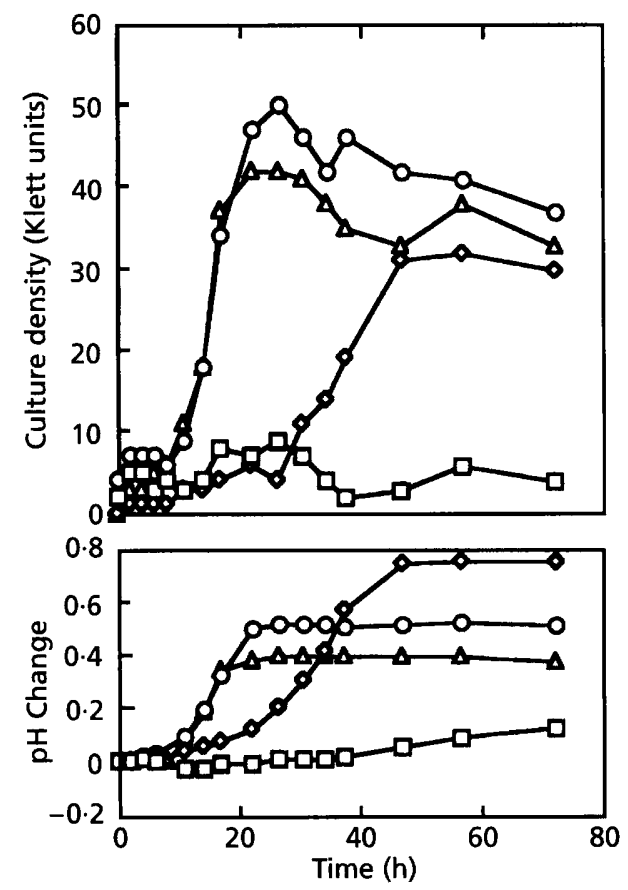

Fig. 1. Growth and $\mathrm{pH}$ changes observed in cultures of $R$. meliloti 104A14 started at different $\mathrm{pH}$ values in MM medium containing $3 \mathrm{mM}$ succinate as carbon source. The initial $\mathrm{pH}$ values were $\mathrm{pH} 6.7(\triangle) ; \mathrm{pH} 6.0(0) ; \mathrm{pH} 5.5(\diamond)$. One culture contained $10 \mathrm{mM}$ MES buffer pH $5.5(\square)$.

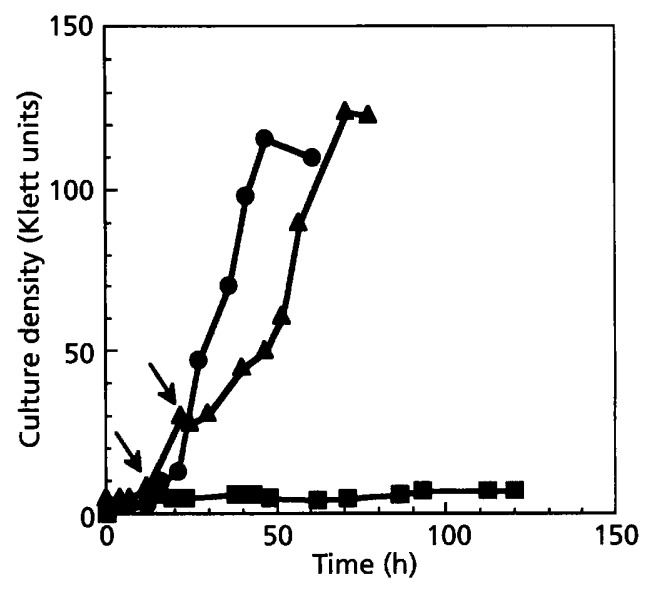

Fig. 2. Growth curves of $R$. meliloti $101 \mathrm{~A} 14$ in MM medium to which $10 \mathrm{mM}$ sodium acetate was added at $\mathrm{pH}$ values of 6.9 (O), 6.5 (A) and 6.2 (G) (arrows). 


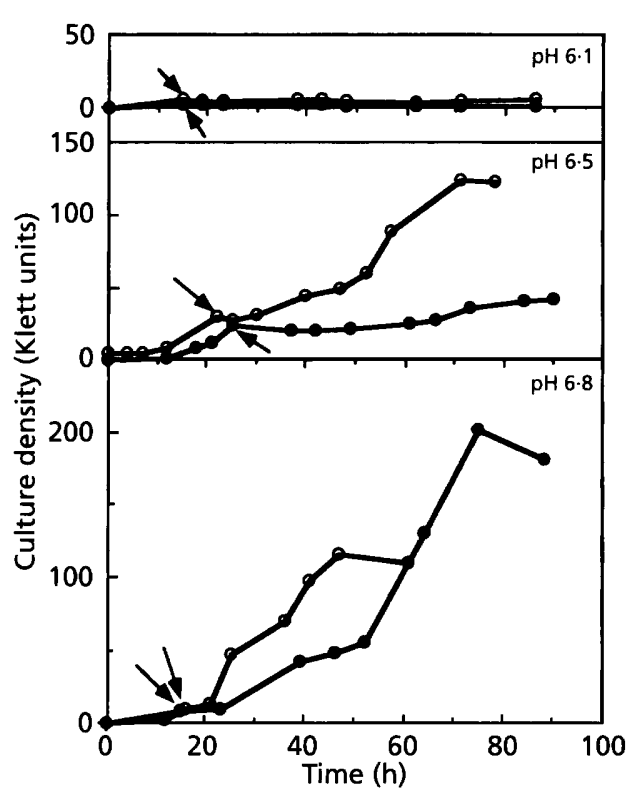

Fig. 3. Growth curves of $R$. meliloti 104A14 in MM medium to which $10 \mathrm{mM}(O)$ or $25 \mathrm{mM}(0)$ sodium acetate was added at $\mathrm{pH}$ values of $6.1,6.5$ and 6.8 . The time of acetate addition is shown by the arrows.

Table 2. Growth of $R$. meliloti strains in the presence of acetate

Each strain was streaked on a separate plate of solid MM medium ( $\mathrm{pH} 6.8$ ) containing sodium acetate at the indicated concentrations in a way that produced well separated colonies at the end of the streak. - , No growth after $14 \mathrm{~d}$; \pm , visible but tiny colonies after $14 \mathrm{~d}$; + , normal sized colonies after $10 \mathrm{~d}$.

\begin{tabular}{|lllllll|}
\hline Strain & \multicolumn{6}{c|}{ Sodium acetate concn $(\mathrm{mM}):$} \\
\cline { 2 - 6 } & & $\mathbf{5 0}$ & $\mathbf{3 7 . 5}$ & $\mathbf{2 5}$ & $\mathbf{1 2 . 5}$ & $\mathbf{6 \cdot 2 5}$ \\
& & & & & \\
\hline 104A14 & - & - & - & + & + \\
Rm1021 & - & - & + & + & + \\
102F34 & - & - & + & + & + \\
$102 F 28$ & - & - & \pm & + & + \\
102 F50Str & - & - & - & + & + \\
\hline
\end{tabular}

Growth inhibition also depended on acetate concentration (Fig. 3). At pH 6.1, both $10 \mathrm{mM}$ and $25 \mathrm{mM}$ acetate were inhibitory in media that contained succinate, but at $\mathrm{pH} 6.5$ growth was observed with $10 \mathrm{mM}$ acetate but not with $25 \mathrm{mM}$. When acetate was added at $\mathrm{pH} 6.8$ the bacterial growth rate between $15 \mathrm{~h}$ (time of addition) and $50 \mathrm{~h}$ was higher in the presence of $10 \mathrm{mM}$ acetate than in presence of $25 \mathrm{mM}$ acetate. The growth rate in $25 \mathrm{mM}$ acetate increased after $50 \mathrm{~h}$, and this coincided with the time at which the $\mathrm{pH}$ rose above $7 \cdot 4$. The increase in the external $\mathrm{pH}$ and the simultaneous alleviation of the inhibition suggests that acetate at low $\mathrm{pH}$ is bacteriostatic rather than bacteriocidal. The number of viable cells recovered on yeast extract mannitol agar did not decrease during the

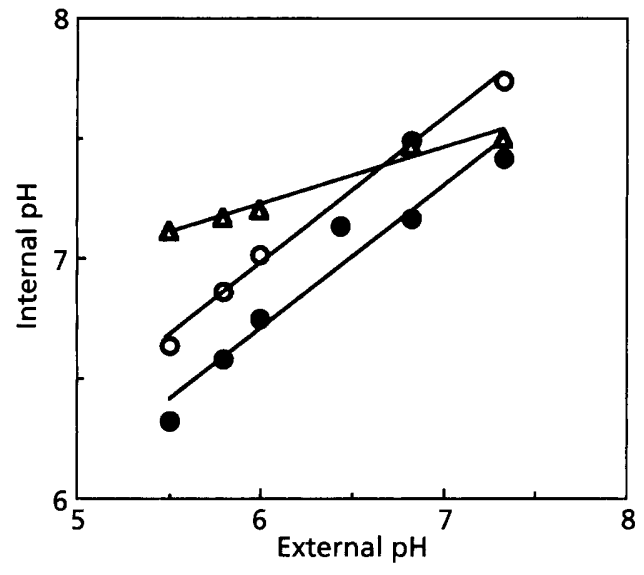

Fig. 4. Effect of sodium acetate at $10 \mathrm{mM}(O)$ or $25 \mathrm{mM}(0)$ on the internal $\mathrm{pH}$ of $R$. meliloti 104A14 at various external $\mathrm{pH}$ values. $\Delta$, Control with $3 \mathrm{mM}$ succinate only. The regression lines have the values (O) $\mathrm{pH}_{\mathrm{i}}=3.40+0.60 \mathrm{pH}_{\mathrm{o}}, R^{2}=0.99$; (O) $\mathrm{pH}_{\mathrm{i}}=3.16+0.59 \mathrm{pH}_{\mathrm{o}}, R^{2}=0.95 ;$ (A) $\mathrm{pH}_{\mathrm{i}}=5.82+0.23 \mathrm{pH}_{\mathrm{o}}$ $R^{2}=0.96$.

period when no growth is observed (data not shown). Bacteriostatic inhibition by acetate had been reported for Clostridium thermoaceticum (Baronofsky et al., 1984). The additional acetate available for use as a carbon source probably accounts for the higher yield of these cultures (Fig. 3) compared to those grown in MM medium (Fig. 1). The effect of acetate on the growth of $R$. meliloti strains unrelated to strain 104A14 that are used in other laboratories was determined. Like 104A14, these strains are inhibited by acetate (Table 2), indicating that this sensitivity is not limited to a specific strain. All of these strains grow well in similar concentrations of succinate.

Acetate can cross bacterial cell membranes by passive diffusion as the undissociated acid (Visser \& Postma, 1973; Salmond et al., 1984; Baronofsky et al., 1984), releasing $\mathrm{H}^{+}$and lowering the internal $\mathrm{pH}$ by dissociating within the cells. Growth inhibition could therefore be due to decreased intracellular $\mathrm{pH}$. To test this, the internal $\mathrm{pH}$ was determined as a function of external $\mathrm{pH}$ and acetate concentration (Fig. 4). In the presence of acetate, the internal $\mathrm{pH}$ varied more rapidly as a function of external $\mathrm{pH}$ than in controls that lacked acetate. This correlated with the stronger inhibitory effect of acetate at both lower external $\mathrm{pH}$ values (Fig. 2) and higher concentrations (Fig. 3).

To study the effect of other monocarboxylic acids on $R$. meliloti, growth and internal $\mathrm{pH}$ measurements were made at various external $\mathrm{pH}$ values in the presence of 10 and $25 \mathrm{mM}$ of the acid (Table 3). Some of these acids were more effective in lowering the internal $\mathrm{pH}$ and inhibiting growth than others. In almost all cases, when a combination of $\mathrm{pH}$, acid species and concentration caused the internal $\mathrm{pH}$ to drop below $7 \cdot 15$, growth was inhibited. These results are consistent with others in the literature. In their survey of acid tolerant strains of $R$. meliloti and acid sensitive mutants, O'Hara et al. (1989) found that growth was inhibited when the internal $\mathrm{pH}$ was below 
Table 3. Effect of organic acids on the internal pH of $R$. meliloti $104 \mathrm{~A} 14$ at various external $\mathrm{pH}$ values

Numbers are means (and standard deviations) from three determinations. Numbers in bold type indicate $\mathrm{pH}$ values where no growth was observed.

\begin{tabular}{|c|c|c|c|c|c|c|c|}
\hline \multirow[t]{2}{*}{ Acid (mM) } & \multirow[t]{2}{*}{$\mathrm{p} K$} & \multicolumn{6}{|c|}{ External $\mathrm{pH}$ value: } \\
\hline & & $5 \cdot 50$ & $5 \cdot 78$ & $6 \cdot 01$ & $6 \cdot 44$ & $6 \cdot 83$ & $7 \cdot 33$ \\
\hline Acetic (10) & $4 \cdot 75$ & $6 \cdot 64(0.02)$ & $6.86(0.07)$ & $7.02(0.03)$ & ND & $7.49(0.02)$ & $7.74(0.08)$ \\
\hline Acetic (25) & & $6.32(0.05)$ & $6.58(0.08)$ & $6.75(0.07)$ & $7 \cdot 14(0.01)$ & $7 \cdot 17(0 \cdot 13)$ & $7 \cdot 42(0 \cdot 13)$ \\
\hline Butyric (10) & $4 \cdot 81$ & $6.69(0.02)$ & $7.01(0.02)$ & $7 \cdot 18(0 \cdot 01)$ & ND & $7 \cdot 66(0 \cdot 06)$ & $7.91(0.03)$ \\
\hline Butyric (25) & & $6.41(0.01)$ & $6.66(0.08)$ & $6.92(0.07)$ & $7.23(0.07)$ & $7 \cdot 58(0.06)$ & $7 \cdot 89(0 \cdot 10)$ \\
\hline DL- $\beta$-OH Butyric (10) & $4 \cdot 81$ & $6.80(0.05)$ & $7.03(0.04)$ & $7 \cdot 19(0 \cdot 06)$ & $7.44(0.06)$ & $7.60(0.06)$ & $7 \cdot 59(0 \cdot 10)$ \\
\hline DL- $\beta$-OH Butyric (25) & & $6.59(0.12)$ & $6.73(0.06)$ & $6.84(0.07)$ & $7 \cdot 27(0 \cdot 02)$ & $7 \cdot 64(0 \cdot 14)$ & $7 \cdot 66(0 \cdot 21)$ \\
\hline Propionic (10) & $4 \cdot 87$ & $6.56(0.08)$ & $6.84(0.05)$ & $7.03(0.02)$ & $7 \cdot 29(0 \cdot 05)$ & $7 \cdot 51(0 \cdot 01)$ & $7 \cdot 59(0 \cdot 11)$ \\
\hline Propionic (25) & & $6.26(0.06)$ & $6 \cdot 47(0 \cdot 14)$ & $6.78(0 \cdot 18)$ & $7.06(0.05)$ & $7.40(0.02)$ & $7 \cdot 51(0 \cdot 14)$ \\
\hline Formic $(10)$ & 3.75 & $6.67(0.03)$ & $6.88(0.03)$ & $7.00(0.01)$ & ND & $7 \cdot 43(0.03)$ & $7.70(0.08)$ \\
\hline Formic $(25)$ & & $6.41(0.06)$ & $6.63(0.09)$ & $6.80(0.06)$ & $7.09(0.06)$ & $7 \cdot 51(0 \cdot 17)$ & $7 \cdot 64(0.09)$ \\
\hline Glycolic (10) & $3 \cdot 83$ & $6.80(0.09)$ & $7.02(0.03)$ & $7.09(0.15)$ & $7.52(0 \cdot 17)$ & $7 \cdot 77(0 \cdot 03)$ & $7.85(0.17)$ \\
\hline Glycolic (25) & & $6.43(0.03)$ & $6.71(0.04)$ & $6.90(0.13)$ & $7 \cdot 16(0 \cdot 02)$ & $7.66(0.07)$ & $7 \cdot 62(0 \cdot 16)$ \\
\hline Acetoacetic (10) & $3 \cdot 58$ & $6.79(0.02)$ & $7.08(0.05)$ & $7 \cdot 27(0 \cdot 14)$ & $7 \cdot 42(0 \cdot 12)$ & $7 \cdot 48(0 \cdot 15)$ & $7 \cdot 67(0.17)$ \\
\hline Acetoacetic (25) & & $6.28(0.03)$ & $6.49(0.17)$ & $7.03(0.04)$ & $7.31(0.03)$ & $7 \cdot 31(0 \cdot 16)$ & $7 \cdot 43(0 \cdot 18)$ \\
\hline Control* & & $7 \cdot 11(0 \cdot 04)$ & $7 \cdot 17(0.06)$ & $7.20(0.04)$ & ND & $7.47(0.09)$ & $7 \cdot 50(0 \cdot 17)$ \\
\hline
\end{tabular}

* All incubations were in the presence of $3 \mathrm{mM}$ succinate.

ND, Not determined.

$7 \cdot 0$. Our only exception to this rule was $25 \mathrm{mM}$ propionic acid which was inhibitory at an external $\mathrm{pH}$ of 6.8 when the internal $\mathrm{pH}$ was still $7 \cdot 4$. We suggest that propionate is toxic for some reason other than its ability to lower intracellular $\mathrm{pH}$.

The nitrogenase reaction consumes protons and produces the base, ammonia. It has been suggested that raising the $\mathrm{pH}$ of the symbiosome compartment may be an important consequence of thizobial nitrogen fixation (Udvardi \& Kahn, 1992). The results above show that monocarboxylic acids such as acetic, $\beta$-hydroxybutyric and acetoacetic acid can act together with mild acidity like that found in symbiosomes to inhibit the growth of $\mathrm{R}$. meliloti. Although the concentrations of these monocarboxylic acids in the alfalfa nodule were not reported in the most recent survey of metabolites (Fougère et al., 1991), benzoic acid is present. If pathways of carbon catabolism lead to the production of acids that can move through membranes in their unionized form and if a low symbiosome $\mathrm{pH}$ allows a high enough concentration of these forms to be present, then this synergism could significantly affect bacterial growth and may bias bacterial metabolism toward pathways that either produce fewer organic acids or that consume protons.

\section{ACKNOWLEDGEMENTS}

We thank Drs Angel Gutierrez-Navarro, Michael Udvardi and Timothy McDermott for helpful discussions and Dr GutierrezNavarro for his encouragement in carrying out this work. The research carried out by R.P.-G. at Washington State University was supported by a grant from the Gobierno Autonomo de Canarias. This work was also supported by grants $88-37120$ 3890 and 92-03461 from the USDA Competitive Research Grants Office and by the Agriculture Research Center at Washington State University.

\section{REFERENCES}

Baronofsky, J. J., Schreurs, J. A. \& Kashket, E. R. (1984). Uncoupling by acetic acid limits growth of and acetogenesis by Clostridium thermoaceticum. Appl Environ Microbiol 48, 1134-1139.

Cherrington, C. A., Hinton, M. \& Chopra, I. (1990). Effect of shortchain organic acids on macromolecular synthesis in Escherichia coli. J Appl Bacteriol 68, 69-74.

Cherrington, C. A., Hinton, M., Pearson, G. R. \& Chopra, I. (1991). Inhibition of Escherichia coli $\mathrm{K}-12$ by short-chain organic acids; lack of evidence for induction of the SOS response. $J$ Appl Bacteriol 70, 156-160.

Dijkhuizen, L., van der Werf, B. \& Harder, W. (1980). Metabolic regulation in Pseudomonas oxalaicus OX1. Diauxic growth on mixtures of oxalate and formate or acetate. Arch Microbiol 124, 261-268.

Ditta, G., Stanfield, S., Corbin, D. \& Helinski, D. R. (1980). Broad host range DNA cloning system for Gram-negative bacteria: construction of a gene bank of Rbizobium meliloti. Proc Natl Acad Sci US $A$ 77, 7347-7351,

Eklund, T. (1983). The antimicrobial affect of dissociated and undissociated sorbic acid at different $\mathrm{pH}$ levels. J Appl Bacteriol 54, 383-389.

Eklund, T. (1985). The effect of sorbic acid and esters of $p$ hydroxybenzoic acid on the protonmotive force in Escherichia coli membrane vesicles. J Gen Microbiol 131, 73-76. 
Fougère, F., Le Rudulier, D. \& Streeter, J. G. (1991). Effects of salt stress on amino acid, organic acid and carbohydrate composition of roots, bacteroids, and cytosol of alfalfa (Medicago sativa L.). Plant Pbysiol 96, 1228-1236.

Graham, P. H. \& Parker, C. A. (1964). Diagnostic features in the charactcrization of the root-nodule bacteria of legumes. Plant Soil 20, 383396 .

Kannenberg, E. J. \& Brewin, N. J. (1989). Expression of a cell surface antigen is regulated by oxygen and $\mathrm{pH}$ in Rbizobium leguminosarum strain 3841. J Bacteriol 171, $4543-4548$.

Kashket, E. R. (1981). Proton motive force in growing Streptococcus lactis and Stapbylococcus aureus cells under aerobic and anaerobic conditions. J Bacteriol 146, 369-376.

Maloney, P. C., Kashket, E. R. \& Wilson, T. H. (1975). Methods for studying transport in bacteria. Methods Membr Biol 5, 1-49.

Meade, H. M., Long, S. R., Ruvkun, G. B., Brown, S. E. \& Ausubel, F. M. (1982). Physical and genetic characterization of symbiotic and auxotrophic mutants of Rhizobium meliloti induced by transposon mutagenesis. J Bacteriol 149, 114-122.

Mellor, R. B. (1989). Bacteroids in the Rhizobium-legume symbiosis inhabit a plant internal lytic compartment: implications for other microbial endosymbioses. $J$ Exp Bot 40, 831-839.

Miller, R. W., McRae, D. G., Al-Jobore, A. \& Berndt, W. B. (1988). Respiration supported nitrogenase activity of isolated Rbizobium meliloti bacteroids. J Cell Biochem 38, 35-49.

O'Hara, G. W., Goss, T. J., Dilworth, M. J. \& Glenn, A. R. (1989).
Maintenance of intracellular $\mathrm{pH}$ and acid tolerance in Rbizobium meliloti. Appl Environ Microbiol 55, 1870-1876.

Roberts, J. K. M., Ray, P. M., Wade-Jardetsky, N. \& Jardetsky, O. (1980). Estimation of cytoplasmic and vacuolar $\mathrm{pH}$ in higher plants by ${ }^{31}$ P NMR. Nature 283, 870-872.

Salmond, C. V., Kroll, R. G. \& Booth, I. R. (1984). The effect of food preservatives on $\mathrm{pH}$ homeostasis in Escherichia coli. J Gen Microbiol 130, 2845-2850.

Somerville, J. E. \& Kahn, M. L. (1983). Cloning of the glutamine synthetase I gene from Rhizobium meliloti. J Bacteriol 156, 168-176.

Trembaly, P. A. \& Miller, R. W. (1984). Cytoplasmic membrane of Rhizobium meliloti bacteroids. II. Functional differentiation and generation of membrane potentials. Can J Biochem Cell Biol 62, $592-600$.

Udvardi, M. K. \& Kahn, M. L. (1992). Evolution of the (Brady) Rhizobium -legume symbiosis: why do bacteroids fix nitrogen? Symbiosis 14, 87-101.

Vincent, J. M. (1970). A Manual for the Practical Study of the RootNodule Bacteria. IBP Handbook 15. Oxford: Blackwell Scientific Publishers.

Visser, A. S. \& Postma, P. W. (1973). Permeability of Azotobacter vinelandii to cations and anions. Biochim Biophys Acta 298, 333-340.

Received 19 March 1993; revised 2 November 1993; accepted 23 November 1993. 